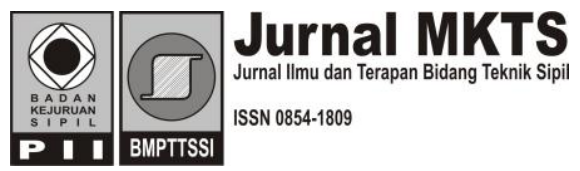

\title{
Unjuk Kerja Waduk Jatigede
}

\author{
Risdiana Cholifatul Afifah \\ Pusat Studi Bencana, LPPM Universitas Diponegoro \\ Gedung Widya Puraya \\ Jl.Prof. Soedarto, SH, Tembalang, Semarang 50275 \\ E-mail: dhianmanis@gmail.com \\ Pranoto Samto Atmodjo \\ Jurusan Teknik Sipil Fakultas Teknik Universitas Diponegoro \\ Jl. Prof. H. Soedarto, SH, Tembalang, Semarang \\ E-mail: pranotosa2001@yahoo.com \\ Sri Sangkawati \\ Jurusan Teknik Sipil Fakultas Teknik Universitas Diponegoro \\ Jl. Prof. H. Soedarto, SH, Tembalang \\ E-mail: srisangkawati@gmail.com
}

\begin{abstract}
Jatigede Reservoir located in Sumedang, West Java. As the second largest reservoir in Indonesia, the main purpose of the reservoir construction is to irrigate the $90.000 \mathrm{Ha}$ of irrigation area, the source of $3,5 \mathrm{~m} 3 / \mathrm{s}$ of raw and drinking water, as well as the source of water for hydropower plan Jatigede requiring water supply as much as 61,84 m3/s. One of the efforts that can be taken to optimize reservoir of water resources, particularly for irrigation water needs, is to do a simulation model of the Jatigede Reservoir operation. This study is discusses the analysis of the performance of the operating pattern Jatigede were analyzed based on the stochastic model of Cimanuk river flow and rain data of Cimanuk Water District. Data needs to be tested first to qualify for a normal statistical distribution using AProb software version 4.1. Stochastic models were analyzed with software SAMS 2007 from Colorado State University. Surgery simulation analysis to determine the performance of the reservoir using software Ribasim. To test the performance of reservoir used the criteria of reliability, resilience, and vulnerability. From the analysis of performance can be concluded that the reliability of the reservoir in an effort to meet the needs of raw water, irrigation, and hydropower at existing condition is of $98.3 \%$, the resilience of the reservoir by $50 \%$, and the vulnerability of dams throughout the simulation period amounted to $6824.70 \mathrm{m3} / \mathrm{s}$, While in the next 50 years the condition of the dam by $92.7 \%$ reliability, resilience reservoir by $34 \%$, and the vulnerability of dams throughout the simulation period amounted 20.540,51 m3/s. It can be concluded that the performance of Jatigede reservoir decreased after the analysis of reservoir operation plan for the next 50 years.
\end{abstract}

Keywords: Ribasim, SAMS 2007, Simulation, Stochastic.

\begin{abstract}
Abstrak
Waduk Jatigede terletak di Kabupaten Sumedang, Jawa Barat. Sebagai waduk kedua terbesar di Indonesia, tujuan utama dibangunnya waduk adalah untuk mengairi Daerah Irigasi Rentang seluas 90.000 Ha, sumber air baku serta air minum sebesar $3,5 \mathrm{~m}^{3} / \mathrm{dt}$, serta sumber air untuk rencana PLTA Jatigede yang membutuhkan suplai air sebanyak $61,84 \mathrm{~m}^{3} / d t$. Salah satu usaha yang dapat ditempuh untuk mengoptimasi sumber daya air waduk, terutama untuk kebutuhan air irigasi, ialah dengan melakukan model simulasi terhadap pengoperasian Waduk Jatigede. Penelitian ini membahas analisis unjuk kerja dari pola operasi Waduk Jatigede yang dianalisis berdasar model stokastik dari data debit Sungai Cimanuk dan hujan DAS Cimanuk. Data perlu diuji terlebih dahulu untuk memenuhi syarat distribusi statistik normal dengan menggunakan perangkat lunak AProb versi 4.1. Model stokastik dianalisis dengan perangkat lunak SAMS
\end{abstract}


2007 dari Colorado State University. Analisis simulasi operasi untuk menentukan unjuk kerja waduk menggunakan perangkat lunak Ribasim. Untuk uji unjuk kerja waduk digunakan kriteria keandalan, kelentingan, dan kerawanan. Dari hasil analisis unjuk kerja dapat disimpulkan bahwa keandalan waduk dalam upaya memenuhi kebutuhan air baku, irigasi, dan PLTA pada kondisi eksisting adalah sebesar $95 \%$, kelentingan waduk sebesar 53\%, dan kerawanan waduk sepanjang periode simulasi sebesar 589.653 juta $\mathrm{m}^{3}$. Sedangkan pada kondisi 50 tahun mendatang keandalan waduk sebesar 92\%, kelentingan waduk sebesar 66 $\%$, dan kerawanan waduk sepanjang periode simulasi sebesar 1.751 miliar $\mathrm{m}^{3}$. Sehingga dapat disimpulkan bahwa unjuk kerja Waduk Jatigede mengalami penurunan setelah pengoperasian waduk selama 50 tahun ke depan.

Kata-kata Kunci: Ribasim, SAMS 2007, Simulasi, Stokastik.

\section{Pendahuluan}

Air merupakan sumber kehidupan bagi manusia. Kita tidak dapat dipisahkan dari senyawa kimia ini dalam kehidupan sehari-hari. Manfaat air bagi kehidupan kita antara lain untuk kebutuhan rumah tangga, kebutuhan industri, air irigasi untuk pertanian sampai pembangkit listrik tenaga air.

Rekayasa manusia untuk lebih mengoptimalkan pemanfaatan sumberdaya air adalah dengan merubah distribusi air alami menjadi distribusi air secara buatan yaitu diantaranya dengan membangun waduk. Waduk merupakan suatu tampungan yang digunakan untuk menampung debit air berlebih pada saat musim hujan supaya kemudian dapat dimanfaatkan pada saat musim kemarau (Sudjarwadi, 1987).

Pada umumnya permasalahan yang timbul pada waduk-waduk di Indonesia adalah kecenderungan penurunan debit air yang masuk ke waduk terutama pada musim kemarau, sehingga volume tampungan efektif waduk berkurang dan mengurangi tingkat keandalan waduk dalam pemenuhan kebutuhannya. Kemarau juga menyusutkan cadangan air waduk. Berdasarkan pemantauan Kementerian PU pada tahun 2012 terhadap waduk-waduk yang tersebar di Indonesia, untuk 3 waduk besar di Jawa Barat yang kondisinya waspada yaitu Saguling, Cirata dan Jatiluhur. Misalnya pada Waduk Jatiluhur terdapat kekurangan air sebesar 187,66 juta $\mathrm{m}^{3}$ dari tampungan normalnya. Hal yang sama juga terjadi di Jawa Tengah, seperti waduk Wonogiri, Cacaban, Rawapening, Gembong, Sudirman. Demikian pula di Jawa Timur terdapat 7 waduk normal, 13 waspada, 1 kering. Sedangkan di Bali dari 5 waduk yang ada, 4 waspada dan 1 kering.

Waduk Jatigede terletak di Kabupaten Sumedang, Jawa Barat. Waduk Jatigede yang berada dalam Daerah Aliran Sungai (DAS) Cimanuk merupakan waduk kedua terbesar di Indonesia dengan tujuan pembangunnya adalah untuk mengairi Daerah Irigasi Rentang seluas 90.000 ha, mencukupi kebutuhan air PLTA Jatigede $67,83 \mathrm{~m}^{3} / \mathrm{dt}$ guna membangkitkan daya listrik sebesar $110 \mathrm{MW}$, dan $3,5 \mathrm{~m}^{3} / \mathrm{dt}$ sebagai sumber air baku serta air minum untuk wilayah Kota Cirebon, Kabupaten Cirebon, Indramayu, dan Majalengka.

Sebelum dibangunnya Waduk Jatigede, sekitar 2,2 miliar $\mathrm{m}^{3}$ air per tahun debit ait Sungai Cimanuk hanya sia-sia terbuang ke laut, padahal di hilir DAS Cimanuk terdapat DI Rentang yang membutuhkan air dalam jumlah besar. Sehingga dengan dibangunnya Waduk Jatigede dapat menampung limpahan air Sungai Cimanuk. Dengan adanya Waduk Jatigede dan pemanfaatanyya di daerah hilir, maka perlu dianalisis unjuk kerja waduk agar pemanfaatannya terhadap inflow dan demand dapat diperhitungkan secara optimal (Balai Data dan Informasi SDA, PSDA Jawa Barat).

Pada tahun 2009, PT. Indah Karya (Persero) telah melakukan simulasi operasi Waduk Jatigede, dengan tujuan untuk menghasilkan pedoman pengoperasian waduk dengan menggunakan trend data inflow dari tahun 1983-2008. Simulasi yang dilakukan oleh PT. Indah Karya tersebut menghasilkan keandalan waduk sebesar $90 \%$. Dalam 492 bulan simulasi, sebanyak 443 bulan daya sebesar 110 MW dapat beroperasi. Sedangkan pada tahun 2013, PT. Multimera Harapan melakukan studi optimasi waduk mengunakan model dynamic programming dan menghasilkan pedoman pengoperasian waduk dengan data inflow dari tahun 1998-2012.

Penelitian ini adalah mengenai unjuk kerja Waduk Jatigede yang dianalisis menggunakan prediksi data inflow dan hujan menggunakan metode stokastik, sehingga dapat diketahui seberapa besar unjuk kerja waduk pada rencana pengoperasian selama 50 tahun ke depan. Data yang digunakan adalah dari tahun 1998-2012. Data yang tidak lengkap sampai tahun 2014 adalah data hujan, sedangkan data inflow sudah lengkap. Sehingga hanya dipakai dimana data hujan dan inflow berada dalam rentang waktu yang sama, yaitu 1998-2012.

Lokasi penelitian adalah Waduk Jatigede yang terletak di Kampung Jatigede Kulon, Desa Cijeungjing, Kecamatan Jatigede, Kabupaten Sumedang (Gambar 1). 


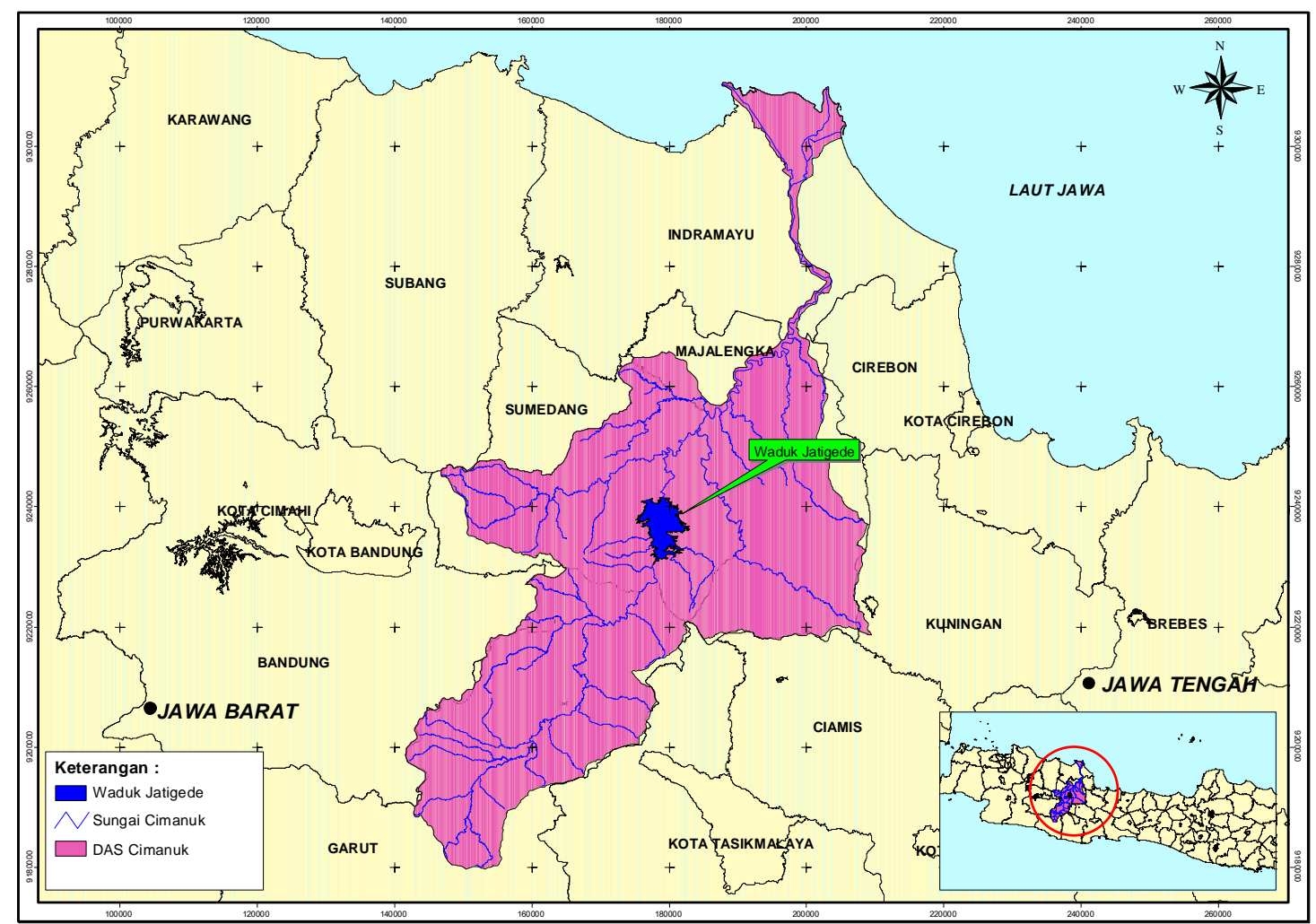

Sumber: PT. Multimera Harapan, 2013

\section{Gambar 1. Peta lokasi Waduk Jatigede}

Prinsip pengoperasian waduk adalah berdasar kepada kebutuhan air baku dan irigasi, sedangkan kebutuhan air PLTA mengikuti pola kebutuhan air semuanya (irigasi dan air baku). Sedangkan alokasi volume tampungan air Waduk Jatigede dapat dilihat pada Gambar 2.

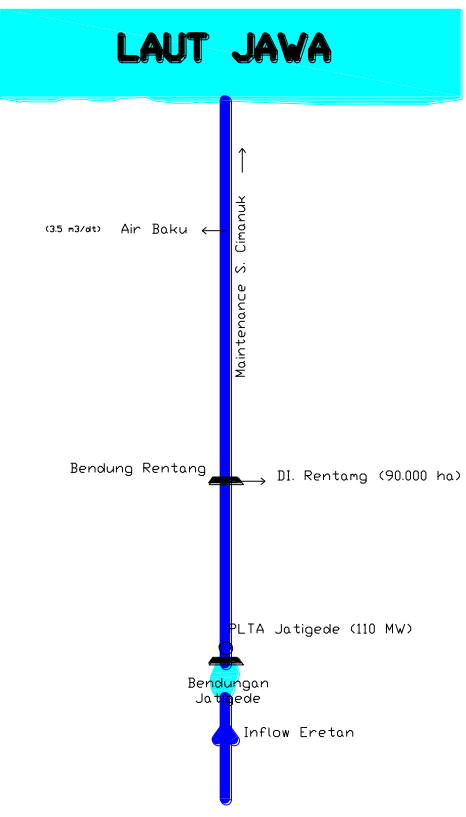

(a)

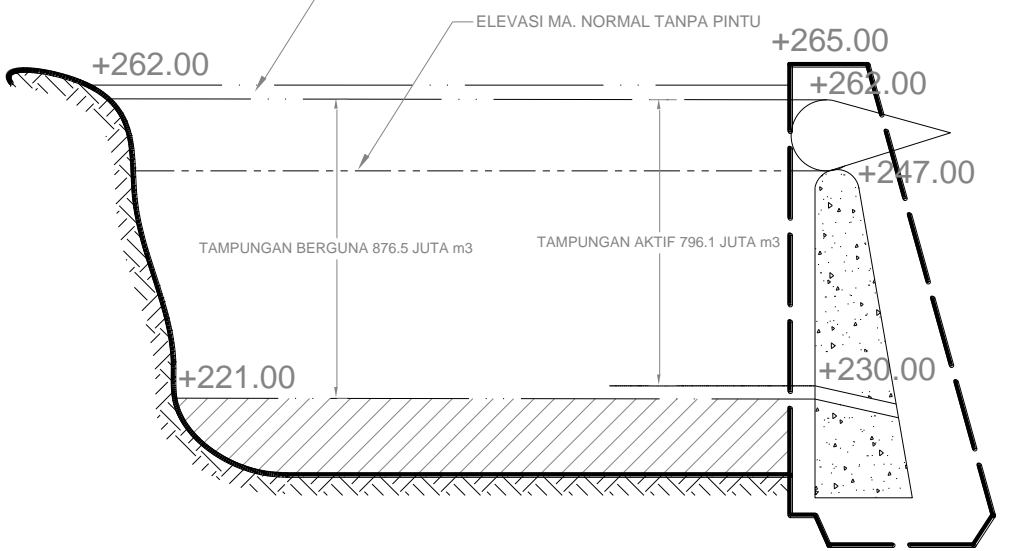

(b)

Gambar 2. (a) Skema tata air Waduk Jatigede, (b) Alokasi volume tampungan air Waduk Jatigede 


\section{Metode Penelitian}

Pelaksanaan penelitian meliputi beberapa kegiatan dan tahapan yang secara skematis ditunjukkan pada Gambar 3.

Dalam studi Unjuk Kerja Waduk Jatigede, datadata yang diperlukan antara lain:

1. Pengumpulan data sekunder yang didapatkan dari instansi-instansi terkait, antara lain:

a. Data kebutuhan air yang diperoleh dari "Laporan Penunjang Hidrologi, Supervisi Pembangunan Waduk Jatigede tahun 2009" yang diterbitkan oleh SNVT Pembangunan Waduk Jatigede

b. Data inflow waduk diperoleh dari pencatatan AWLR Bendung Eretan dan Sta. Debit Parakan Kondang, Kab. Sumedang.Data yang digunakan yaitu 15 tahun, dari tahun 19982012. c. Data curah hujan diperoleh dari BBWS Cimanuk-Cisanggarung.Data curah hujan yang digunakan yaitu dari tahun 1998-2012.

d. Data klimatologi yang digunakan yaitu penguapan, yang diperoleh dari BMKG Jatiwangi, Kab.Majalengka dari tahun 19982012.

e. Data teknis waduk diperoleh dari BBWS Cimanuk-Cisanggarung.

f. Peta DAS Cimanuk diperoleh dari BBWS Cimanuk-Cisanggarung.

g. Peta Daerah Irigasi Rentang diperoleh dari BBWS Cimanuk-Cisanggarung.

h. Data Pola Tanam diperoleh dari "Laporan Penunjang Hidrologi, Supervisi Pembangunan Waduk Jatigede tahun 2009" yang diterbitkan oleh SNVT Pembangunan Waduk Jatigede

i. Kurva Tampungan Waduk eksisting pada tahun 2009 dan kurva tampungan waduk plus sedimen diperoleh dari BBWS CimanukCisanggarung

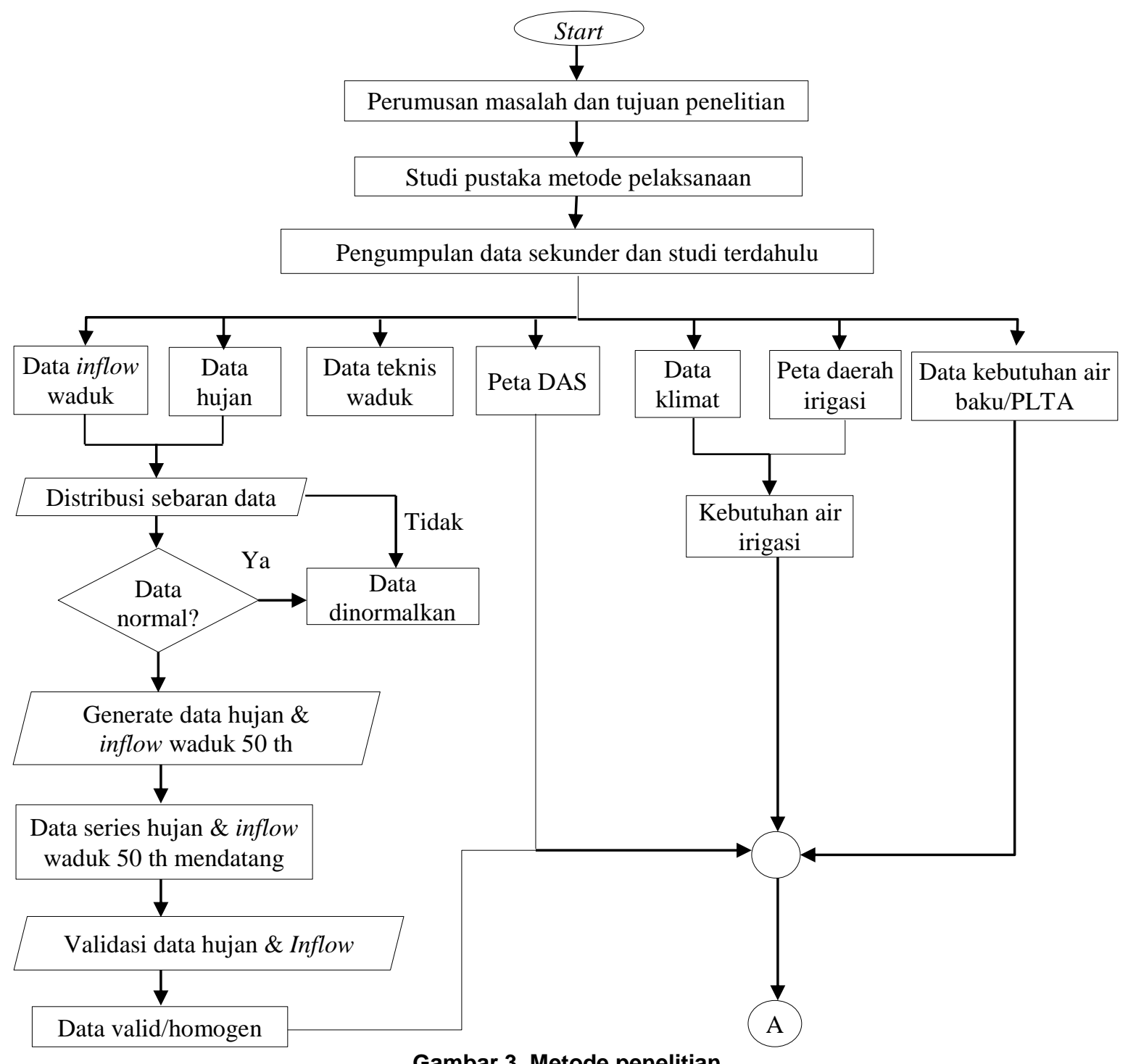

Gambar 3. Metode penelitian 


\section{Analisis distribusi sebaran data}

Analisis distribusi data menggunakan Program AProb versi 4.1 dari Universitas Gajah Mada, serta memplotkan data tersebut menurut distribusi: Gumbel, Log Normal, Log Pearson Tipe III, dan Normal.

3. Analisis peramalan/generate data

Perangkat lunak SAMS 2007 dari Colorado State Universitydigunakan untuk menurunkan atau membangkitkan data debit dan hujan sintetik rata-rata 2-mingguan dengan menggunakan metode unvariate seasonal PARMA.

4. Validitas data bangkitan/hasil generate

Data sekunder yang akan dipergunakan dalam analisis perhitungan selanjutnya perlu diuji validitasnya. Dalam menguji validitas data dipergunakan uji homogenitas (keseragaman), baik berdasarkan pada harga rata-rata maupun pada harga simpangan baku.

5. Simulasi operasi waduk

Pada penelitian unjuk kerja Waduk Jatigede dilakukan pula simulasi dengan menggunakan perangkat lunak RIBASIM versi 6.33 dengan manfaat untuk menentukan keseimbangan antara kebutuhan air dan ketersedian sumber air (neraca air).

\section{Unjuk kerja waduk}

Bahasan akhir dari penelitian ini adalah menganalisis unjuk kerja (performance) Waduk Jatigede yang meliputi :

1. Keandalan

2. Kelentingan

3. Kerawanan

\section{Hasil dan Pembahasan}

\section{Analisis distribusi sebaran data}

Pada pengukuran dispersi tidak semua nilai dari suatu variabel hidrologi terletak atau sama dengan nilai rata-ratanya akan tetapi kemungkinan ada nilai yang lebih besar atau lebih kecil daripada nilai rata-ratanya. Data harus diurutkan dari kecil ke besar untuk kemudian diplotkan pada Program AProb 4.1. Setelah didapatkan parameterparameter statistik, kemudian diuji dengan Chi Kuadrat dan Smirnov Kolmogorof. Gambar plotting data pada Probability Paper dapat dilihat pada Gambar 4.(a) dan Gambar 4.(b).

\section{Analisis peramalan/generate data inflow dan hujan}

Data yang digunakan untuk input model SAMS 2007 yaitu inflow waduk rata-rata 2- mingguan,dan hujan rata-rata 2-mingguan. Data inflow dan hujan sintetik periode 2- mingguan selama 15 tahun, yaitu dari tahun 1998-2012 diturunkan dengan metode PARMA sebanyak 50 seri data debit sintetik. Grafik inflow waduk dan hujan ditampilkan pada Gambar 5.

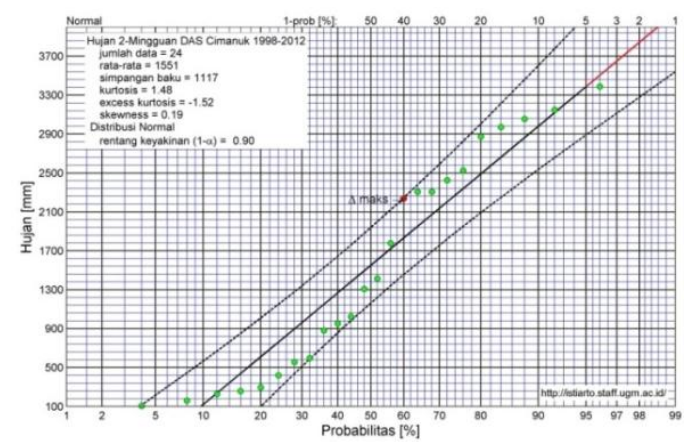

(a)

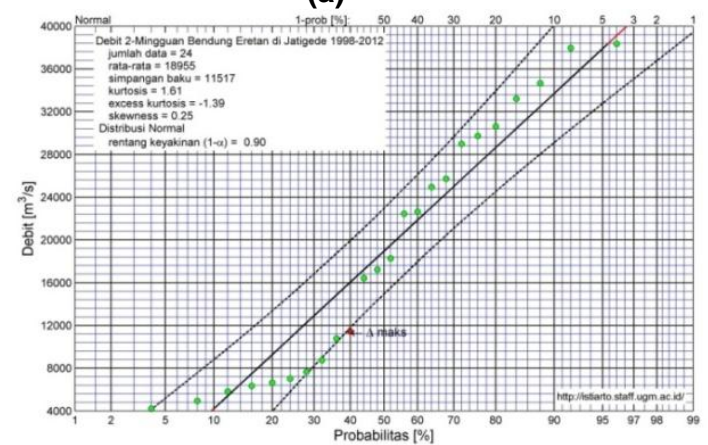

(b)

Gambar 4. (a) Plotting normal probability paper data hujan, (b) Plotting normal probability paper data inflow

Dalam metode time series, alat utama untuk mengidentifikasi model dari data yang akan diramalkan adalah dengan melihat kestasioneran data menggunakan fungsi Autokorelasi parsial/Partial Autocorrelation Function (PACF). Data dikatakan stasioner bila data tidak berubah sepanjang waktu, dengan kata lain proses dalam seimbang secara statistik.

Pada Gambar 6 memperlihatkan plot PACF untuk data sudah stasioner, dimana hanya ada satu lag saja yang signifikan, sedangkan lag-lag lainnya berada di dalam daerah interval. Sedangkan Gambar 7 memperlihatkan plot PACF untuk data historis belum stasioner, dimana ada beberapa lag yang berada di luar daerah interval. Sehingga harus dilakukan transformasi data, agar data menjadi stasioner. Setelah dilakukan transformasi data, dapat dilihat bahwa data sudah stasioner, karena time series data berada di dalam interval. 


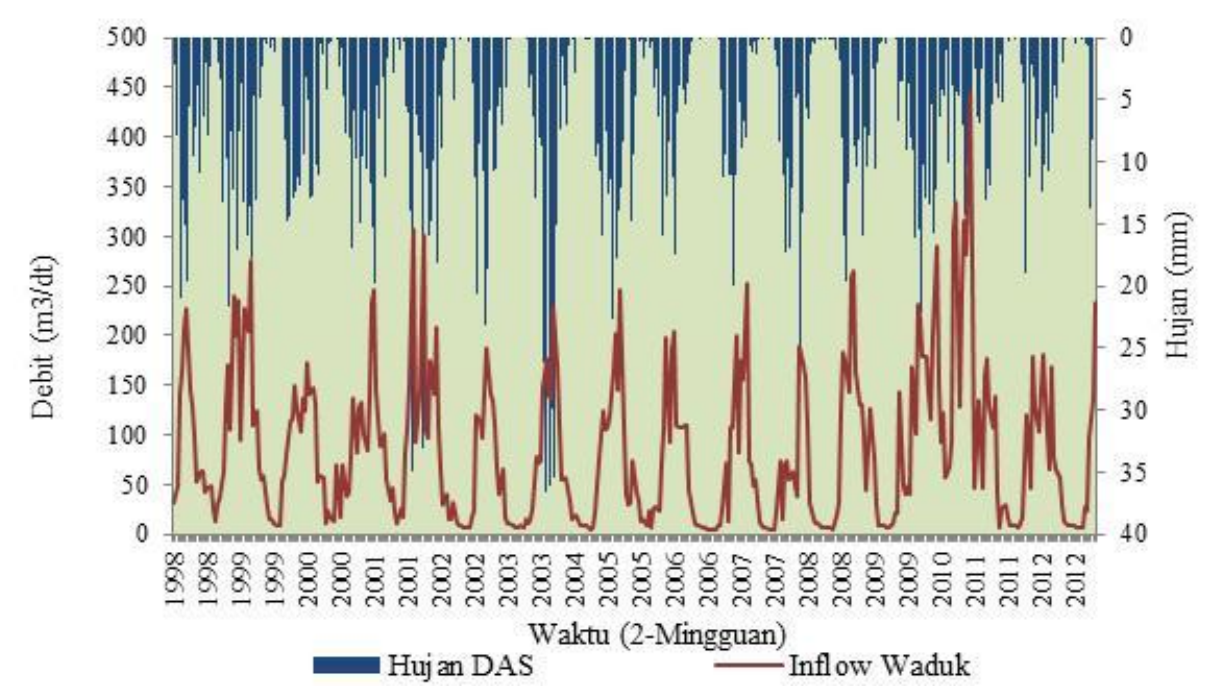

Gambar 5. Data rata-rata 2-mingguan inflow Waduk Jatigede dan hujan DAS Cimanuk

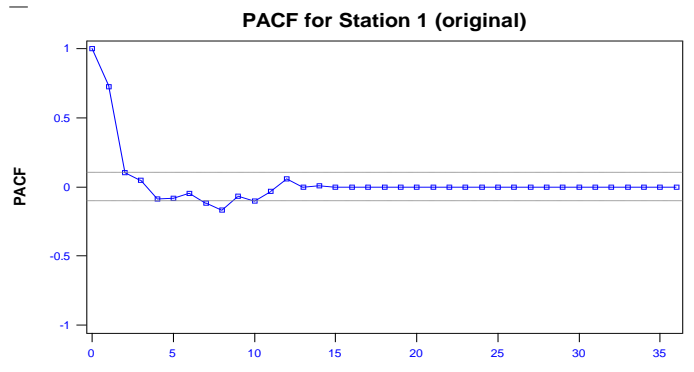

Gambar 6. Plot PACF data inflow

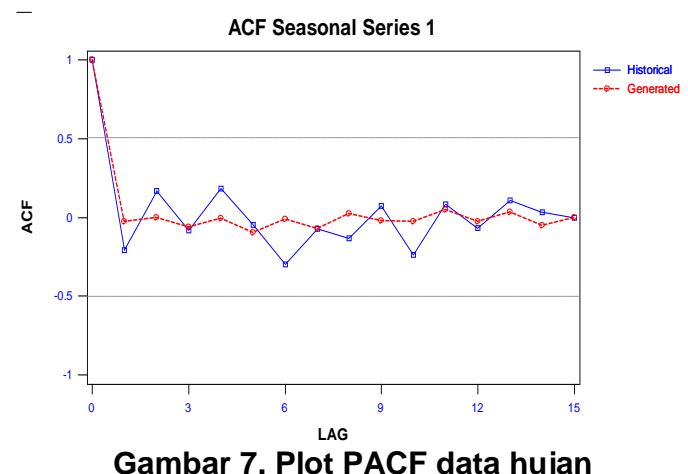

Hasil generate data inflow dan hujan ditampilkan dalam grafik seperti yang dapat dilihat pada Gambar 8 dan Gambar 9.

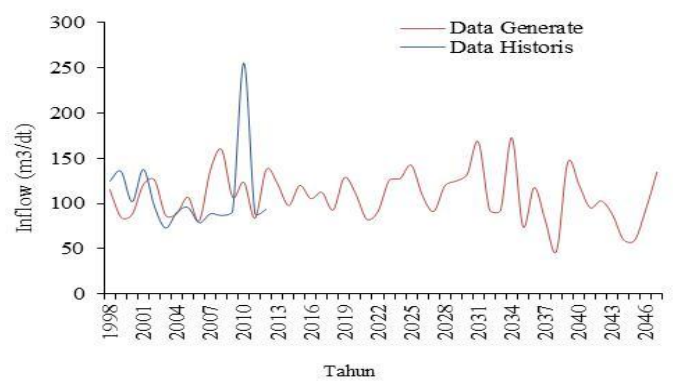

Gambar 8. Inflow rata-rata tahunan Waduk Jatigede hasil analisis generate

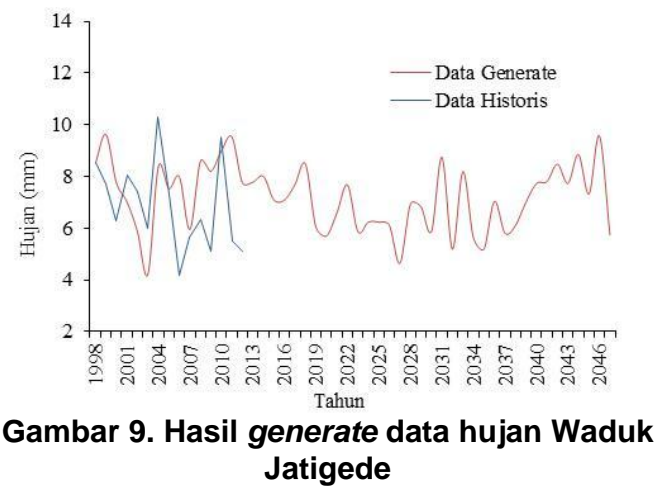

Pada grafik di atas dapat disimpulkan bahwa perbandingan antara time series data historis dan generated pada 15 tahun pertama relatif berbeda. Namun bukan berarti gagal dalam generate data, karena yang diperbandingkan adalah parameter statistik, yaitu rerata data (mean) dan standar deviasi (varian) dari data historis dan hasil generated. Sedangkan 35 tahun ke belakang mengikuti trend data awal.

Dari generate data hujan dan inflow, maka kemudian dilihat nilai mean dan varian untuk setiap periode 2-mingguan. Hasilnya digambar sebagai grafik untuk membandingkan dengan nilai mean dan varian dari data hasil pencatatan. Nilai perbandingan kedua parameter statistik data sintetik dan data hasil pengukuran dapat dilihat pada Tabel 1.

\section{Validasi data bangkitan/hasil generate}

Validasi data hasil bangkitan, dilakukan dengan uji kesamaan nilai mean dan varian antara dua populasi. Untuk uji homogenitas (keseragaman), rangkaian data sepanjang 50 tahun dibagi 2 kelompok yaitu kelompok data historis sepanjang 15 tahun dan kelompok data bangkitan sepanjang 35 tahun. 
Tabel 1. Perbandingan mean dan varian

\begin{tabular}{ccccccccc}
\hline & \multicolumn{3}{c}{ Inflow } & \multicolumn{3}{c}{ Hujan } \\
\cline { 2 - 8 } Periode & \multicolumn{2}{c}{ Mean } & Standar deviasi & \multicolumn{2}{c}{ Mean } & Standar deviasi \\
\cline { 2 - 8 } & $\begin{array}{c}\text { Data } \\
\text { historis }\end{array}$ & $\begin{array}{c}\text { Data } \\
\text { generate }\end{array}$ & $\begin{array}{c}\text { Data } \\
\text { historis }\end{array}$ & $\begin{array}{c}\text { Data } \\
\text { generate }\end{array}$ & $\begin{array}{c}\text { Data } \\
\text { historis }\end{array}$ & $\begin{array}{c}\text { Data } \\
\text { generate }\end{array}$ & $\begin{array}{c}\text { Data } \\
\text { historis }\end{array}$ & $\begin{array}{c}\text { Data } \\
\text { generate }\end{array}$ \\
\hline 1-Jan & 10,89 & 10,53 & 6,11 & 5,94 & 143,80 & 143,50 & 71,91 & 73,34 \\
2-Jan & 14,12 & 13,67 & 9,13 & 8,73 & 165,30 & 165,50 & 81,92 & 79,01 \\
1-Feb & 13,21 & 12,82 & 8,01 & 7,60 & 171,30 & 172,40 & 55,72 & 55,43 \\
2-Feb & 12,71 & 12,69 & 7,58 & 7,47 & 189,40 & 190,00 & 73,65 & 71,61 \\
1-Mar & 13,95 & 14,41 & 7,97 & 7,44 & 215,20 & 216,80 & 50,63 & 50,14 \\
2-Mar & 11,97 & 12,19 & 3,65 & 3,79 & 204,80 & 206,10 & 56,80 & 59,24 \\
1-Apr & 10,64 & 10,86 & 4,90 & 4,91 & 210,10 & 217,10 & 72,20 & 73,16 \\
2-Apr & 5,96 & 5,99 & 2,35 & 2,47 & 146,50 & 148,00 & 59,27 & 59,47 \\
1-Mei & 6,20 & 5,82 & 4,28 & 4,24 & 107,70 & 105,10 & 56,01 & 55,66 \\
2-Mei & 3,74 & 3,72 & 3,64 & 3,71 & 89,87 & 85,06 & 84,84 & 84,51 \\
1-Jun & 3,67 & 4,00 & 4,64 & 4,21 & 65,24 & 62,66 & 50,58 & 50,28 \\
2-Jun & 2,23 & 2,44 & 2,84 & 2,84 & 50,02 & 47,88 & 36,81 & 35,46 \\
1-Jul & 1,04 & 1,03 & 1,63 & 1,62 & 36,84 & 35,60 & 35,85 & 35,00 \\
2-Jul & 1,27 & 1,21 & 2,20 & 2,18 & 28,83 & 27,88 & 21,09 & 20,71 \\
1-Agt & 0,85 & 0,87 & 2,53 & 2,53 & 21,43 & 20,64 & 22,08 & 21,43 \\
2-Agt & 0,50 & 0,52 & 1,01 & 1,00 & 25,14 & 24,54 & 32,49 & 32,07 \\
1-Sep & 1,31 & 1,37 & 3,85 & 3,72 & 40,19 & 39,04 & 96,66 & 95,38 \\
2-Sep & 0,58 & 0,59 & 1,15 & 1,10 & 42,30 & 41,07 & 104,60 & 103,40 \\
1-Okt & 2,62 & 2,63 & 2,35 & 2,41 & 39,13 & 38,97 & 46,76 & 47,64 \\
2-Okt & 4,09 & 3,88 & 3,62 & 3,74 & 59,45 & 58,14 & 76,99 & 78,97 \\
1-Nop & 8,17 & 7,97 & 5,39 & 5,33 & 101,20 & 99,26 & 101,20 & 103,10 \\
2-Nop & 13,53 & 13,33 & 7,11 & 7,03 & 143,70 & 141,60 & 115,60 & 117,10 \\
1-Des & 10,50 & 10,44 & 5,54 & 5,53 & 149,90 & 144,40 & 124,40 & 125,10 \\
2-Des & 9,78 & 9,80 & 3,88 & 3,59 & 174,00 & 168,50 & 85,46 & 81,30 \\
\hline
\end{tabular}

Tabel 2. Perbandingan tc mean dan tc varian dengan tc kritis

\begin{tabular}{lcccc}
\hline \multicolumn{1}{c}{ Data } & tc mean & tc varian & t kritis & Keterangan \\
\hline Inflow & 0,53 & 0,43 & 1,678 & Data homogen \\
Hujan & 0,39 & 1,02 & 1,678 & Data homogen \\
\hline
\end{tabular}

Pada validasi data hujan dan inflow, dengan menggunakan tabel student $\mathrm{t}$ dengan tingkat kepercayaan $\alpha=5 \%$ dan derajat kebebasan $(\mathrm{n} 1+\mathrm{n} 2-2)$ diperoleh $\mathrm{t}_{(0,05 ; 48)}$, kemudian dilakukan interpolasi dihasilkan $\mathrm{t}$ kritis $=1,678$, sehingga perbandingan antara tc mean dan tc varian dengan t kritis dapat dilihat pada Tabel 2.

\section{Simulasi operasi waduk}

Pola operasi waduk yang dianalisis dalam studi ini menggunakan pendekatan simulasi dengan model Ribasim, Simulasi bertujuan untuk mengetahui kondisi fluktuasi muka air waduk dan volume tampungan waduk dalam jangka panjang, yang dioperasikan sesuai batas-batas elevasi yang ditetapkan dalam perencanaan. Kondisi pengoperasian waduk adalah dengan batas atas/full reservoir pada elevasi +260 , yaitu di atas pintu spillway (dalam kondisi pintu tertutup). Batas bawah pengoperasian adalah pada elv +230 , yaitu di intake waduk. Dengan adanya pintu spillway maka kapasitas tampungan diantara spillway dan full reservoir ini bersifat dinamik, karena apabila pintu dibuka, air akan melimpas dan kapasitas tampungan berkurang.

Simulasi yang pertama dilakukan adalah simulasi kondisi eksisting (kondisi awal yaitu ketika waduk pada awal operasi). Simulasi kedua yaitu simulasi waduk pada kondisi 50 tahun mendatang dengan memperhatikan laju sedimen yang mengendap di dasar waduk sesuai dengan studi yang pernah dilakukan oleh Tim Supervisi Waduk Jatigede.

\section{Simulasi kondisi eksisting}

Grafik inflow dan hujan rata-rata 2-mingguan kondisi eksisting dapat dilihat pada Gambar 10.a, kemudian data evaporasi ditampilkan pada Gambar 4. 


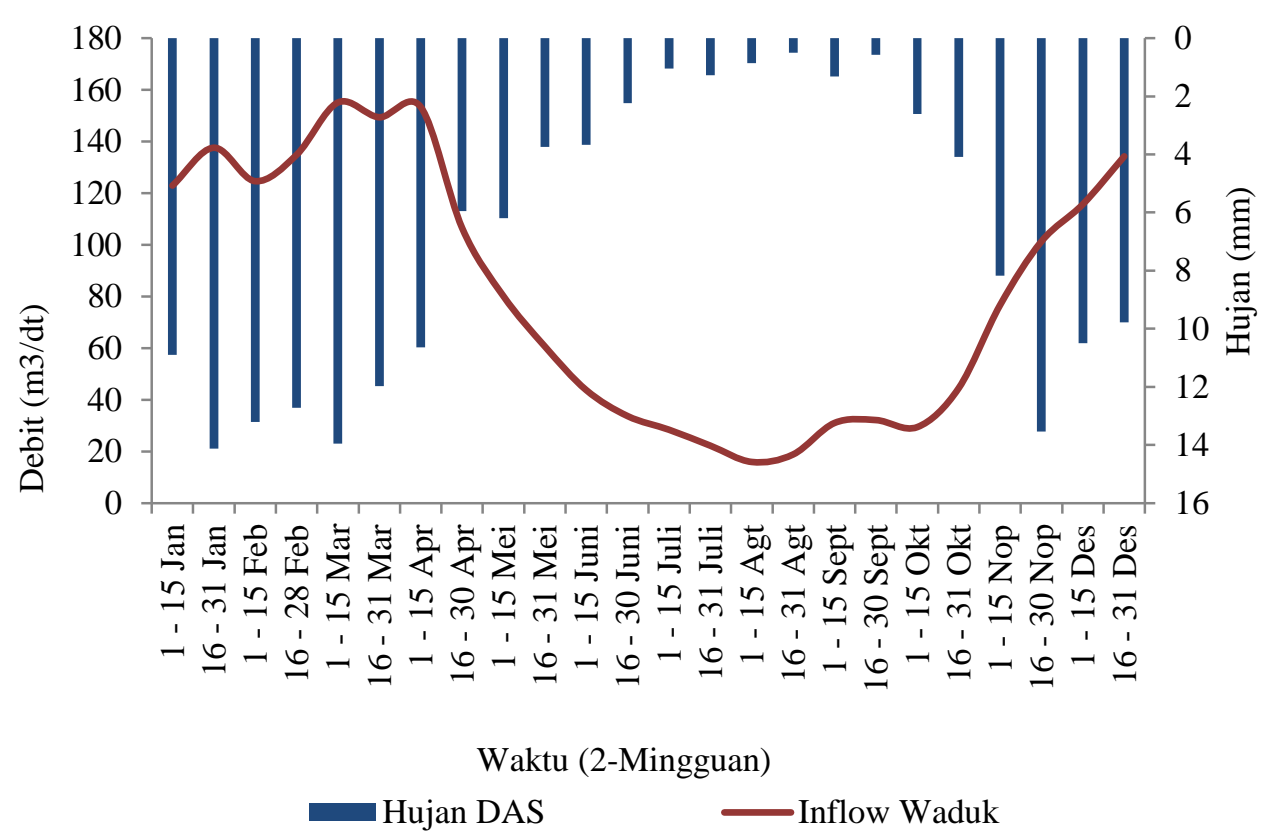

(a)

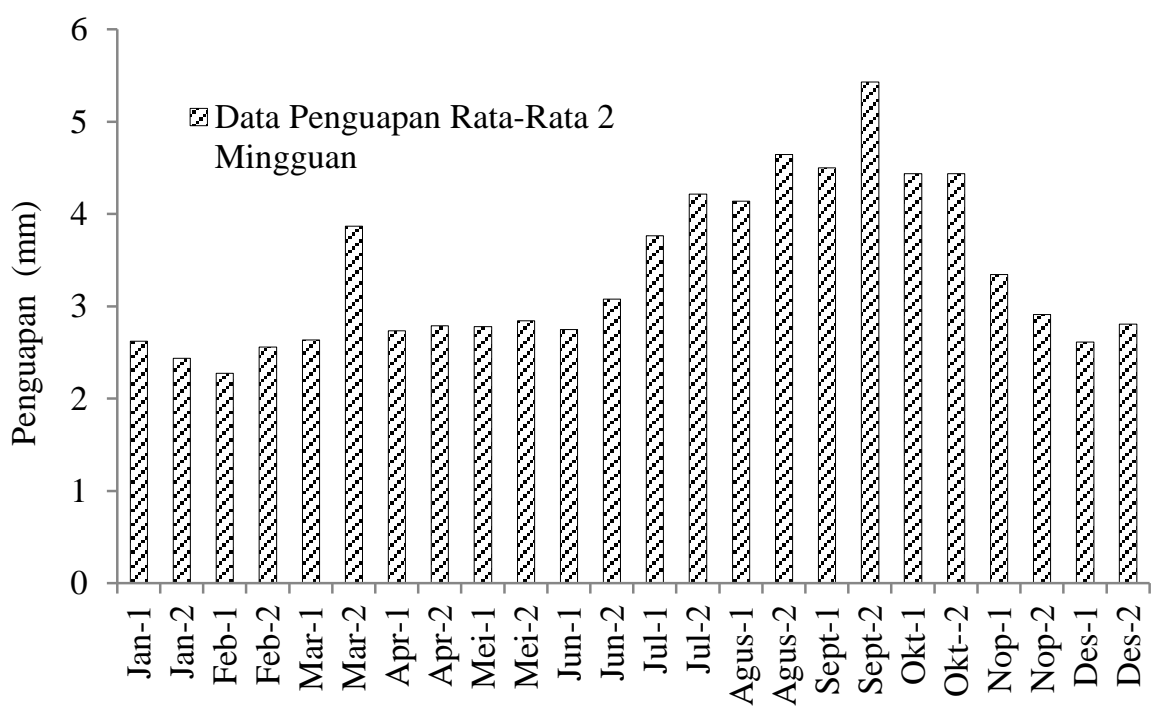

Waktu (2-Mingguan)

(b)

Gambar 10. (a) Grafik inflow \& hujan rata-rata 2-mingguan tahun 1998 - 2012. (b) Data penguapan ratarata 2 mingguan Sta. Jatiwangi

\section{Analisis simulasi ribasim}

Analisis dimulai dengan membuat jejaring DAS Cimanuk dengan node inflow sebagai input debit Waduk Jatigede yang dapat dilihat pada Gambar 11.(a). dan didukung oleh data kurva tampungan waduk yang ditampilkan pada Gambar 11.(b). luas DAS dan Sub DAS, data teknis waduk, data pola tanam, demand air baku, dan data teknis rencana PLTA Jatigede.
Dari hasil running Ribasim kondisi eksisting dapat dilihat bahwa pada awal operasi waduk, kebutuhan air baku, irigasi, dan PLTA dapat terpenuhi. Grafik suplai dan demand ditampilkan pada Gambar 12 (a) dan Gambar 12 (b). Sedangkan pola operasi tahunan dapat dilihat pada Gambar 13. 


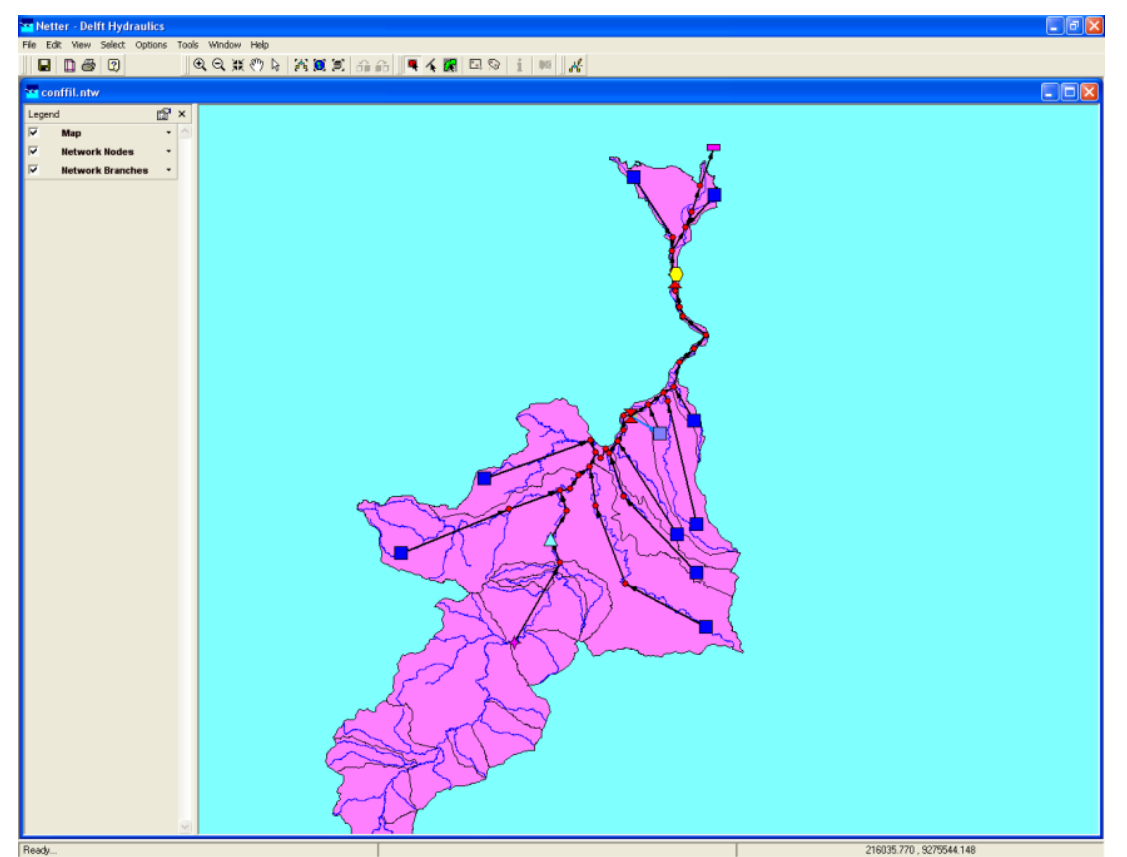

(a)

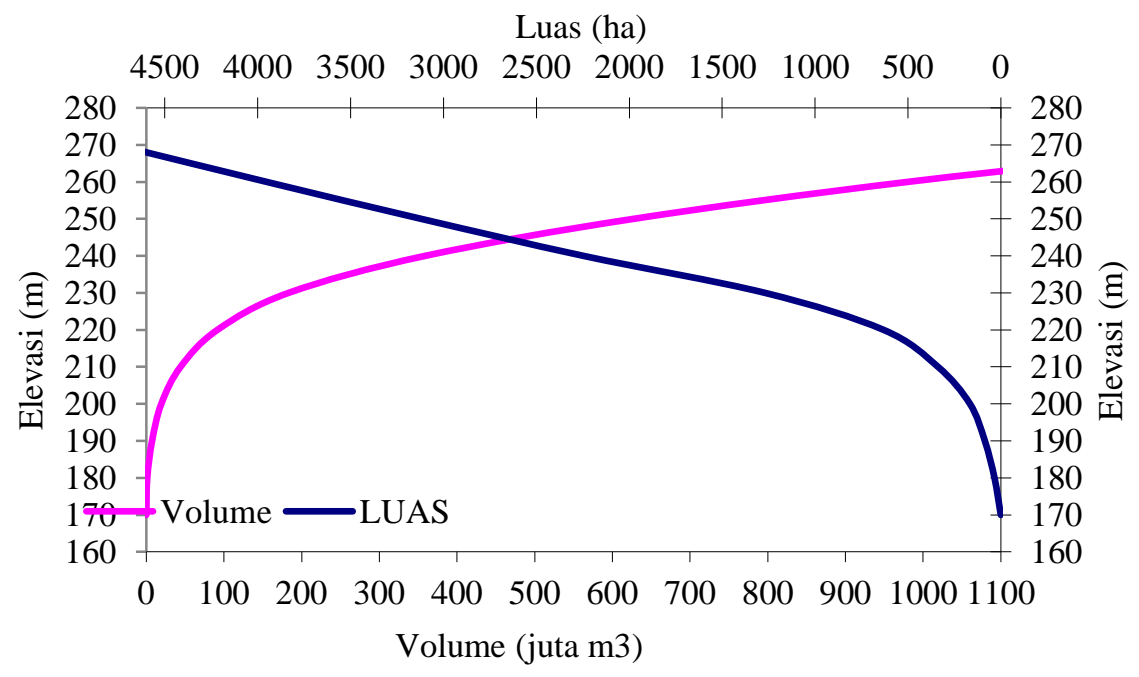

(b)

Gambar 11. (a) Jejaring DAS Cimanuk. (b) Kurva tampungan Waduk Jatigede

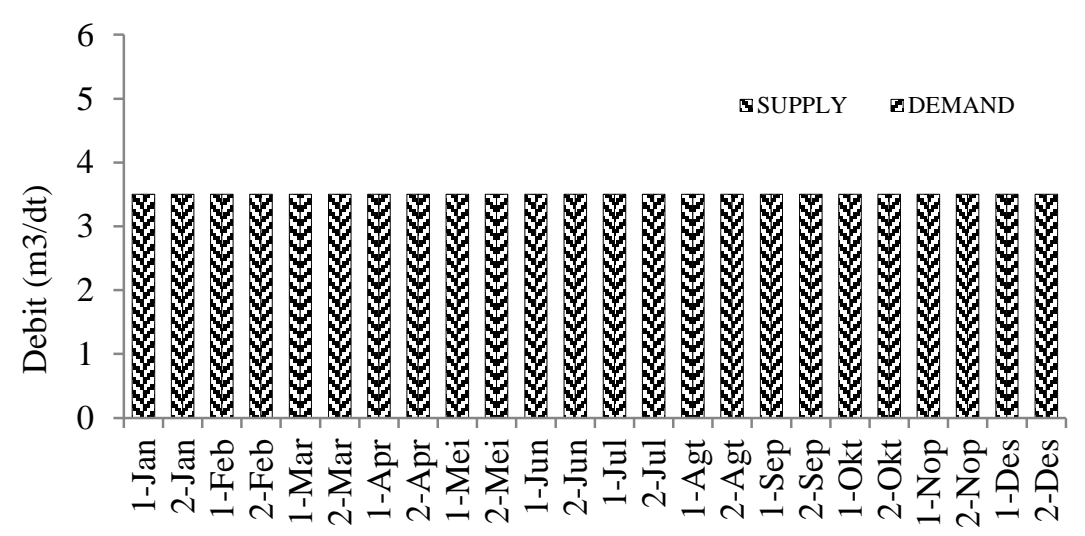

Periode

a) 


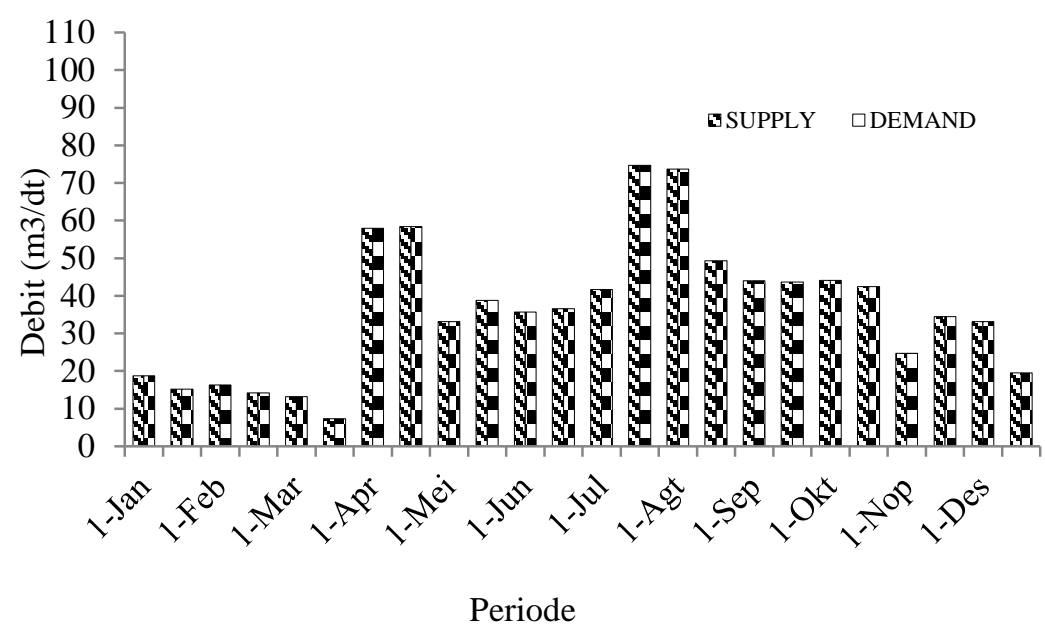

b)

Gambar 12. (a) Demand dan supply air baku. b) Irigasi kondisi eksisting

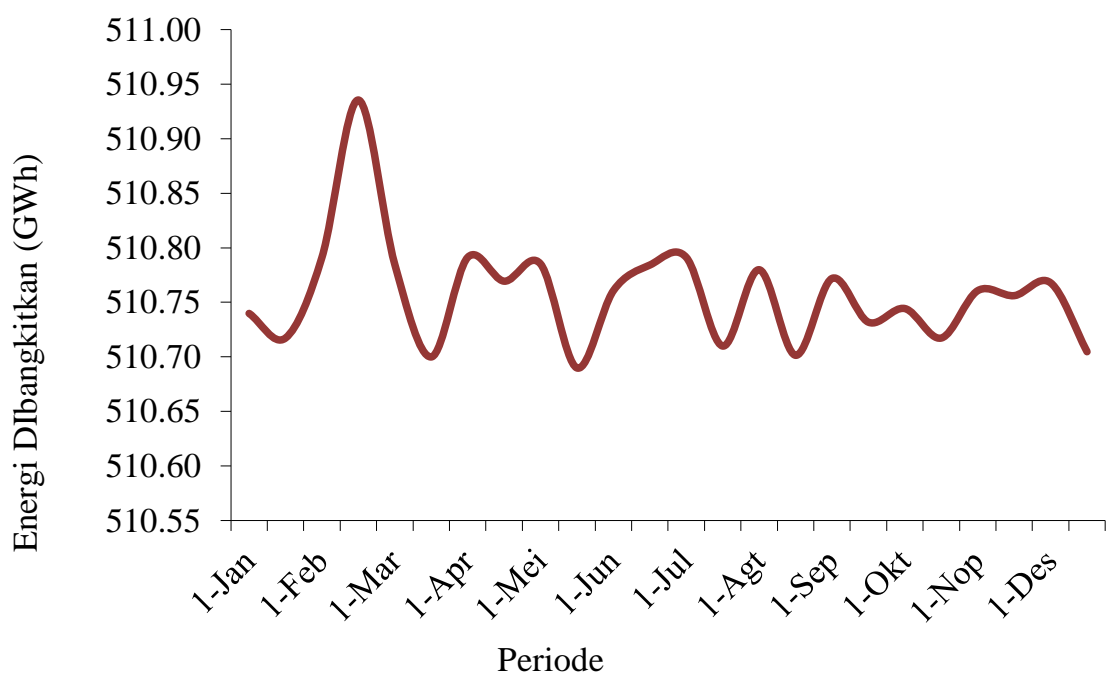

Gambar 13. Demand dan supply PLTA kondisi eksisting

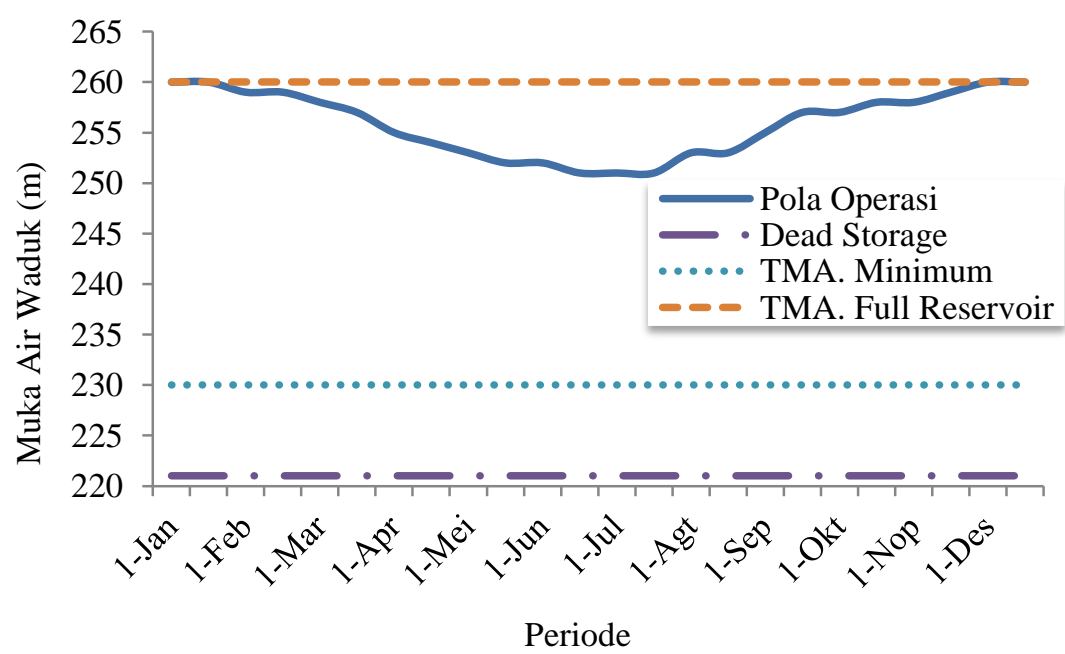

Gambar 14. Pola operasi Waduk Jatigede 
Dapat dilihat pada kurva pola operasi di atas, bahwa elevasi awal = elevasi akhir, karena pada musim hujan debit/inflow melimpah, tampungan waduk penuh sehingga pintu intake harus ditutup. Ketika musim kemarau, elevasi muka air menyusut, sehingga pintu intake harus dibuka, dan konsep pola operasinya mengikuti pada gambar di atas.

\section{Simulasi kondisi 50 tahun mendatang}

Pada simulasi dengan kondisi mendatang menggunakan input data hidrologi (inflow, hujan, dan air larian) hasil generate data dari tahun 1998-2047.

Data teknis untuk simulasi kondisi mendatang yaitu tampungan waduk berubah karena proses sedimentasi di dasar waduk selama 50 tahun. Dari studi yang dilakukan oleh Tim Supervisi Bendungan Jatigede, diketahui laju sedimentasi Waduk Jatigede sebesar 7,77 juta $\mathrm{m}^{3} /$ tahun. Selama kurun waktu 50 tahun sedimen yang

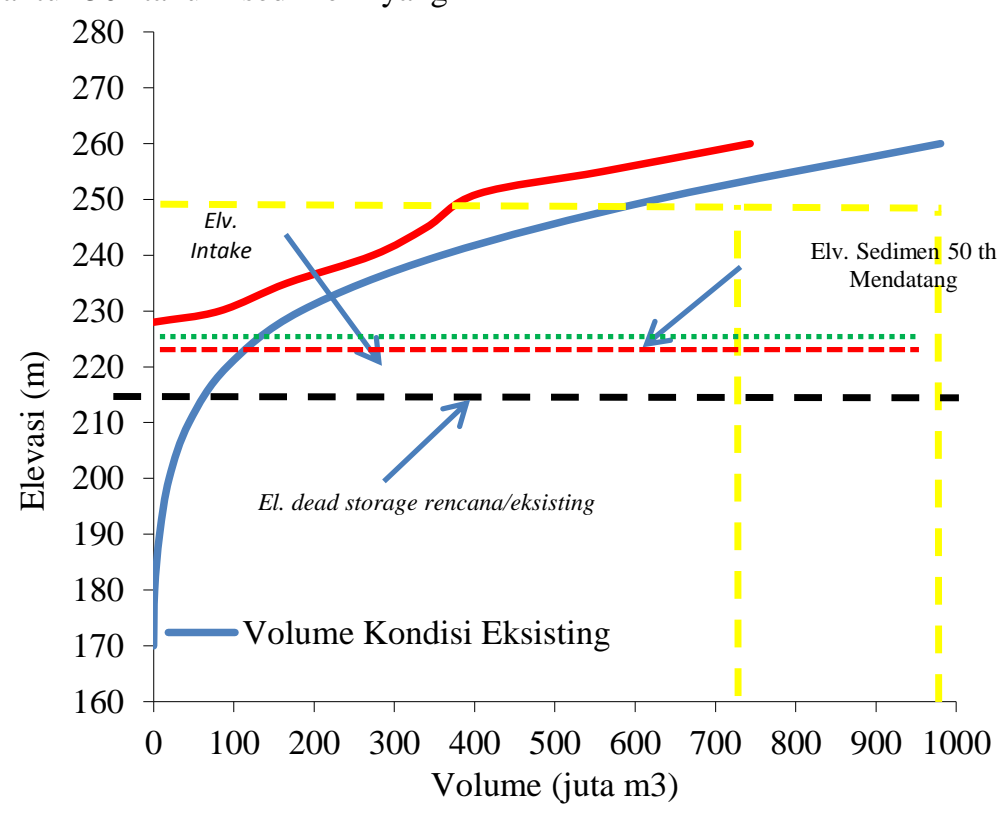

Gambar 15. Kurva tampungan waduk kondisi 50 tahun mendatang

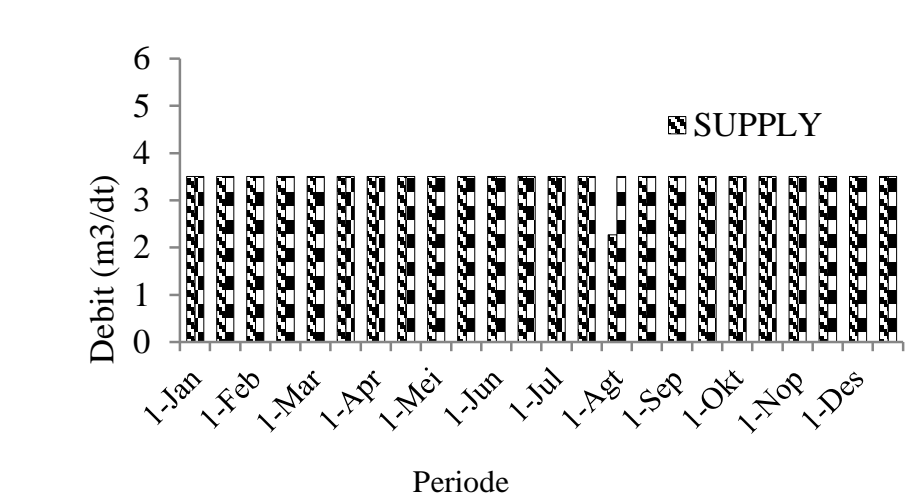

a) mengendap di dasar waduk pada elevasi $+221,00$ adalah sebesar 236,220 juta $\mathrm{m}^{3}$. Sehingga dengan adanya distribusi sedimen di tampungan Waduk Jatigede didapatkan kurva tampungan waduk kondisi mendatang seperti ditampilkan pada Gambar 14.

\section{Hasil running simulasi ribasim kondisi $\mathbf{5 0}$ tahun mendatang}

Dari hasil running Ribasim kondisi 50 tahun mendatang, dapat dilihat bahwa kebutuhan air baku, irigasi, dan PLTA terdapat defisit kebutuhan air irigasi pada musim kemarau, yaitu diantara minggu kedua bulan Juli sampai dengan minggu pertama bulan September. Sedangkan defisit air baku terjadi pada dua minggu pertama bulan agustus. Grafik suplai dan demand ditampilkan pada Gambar 15. Pola operasi tahunan pada kondisi 50 tahun mendatang dapat dilihat pada Gambar 16.

\footnotetext{
)
} 


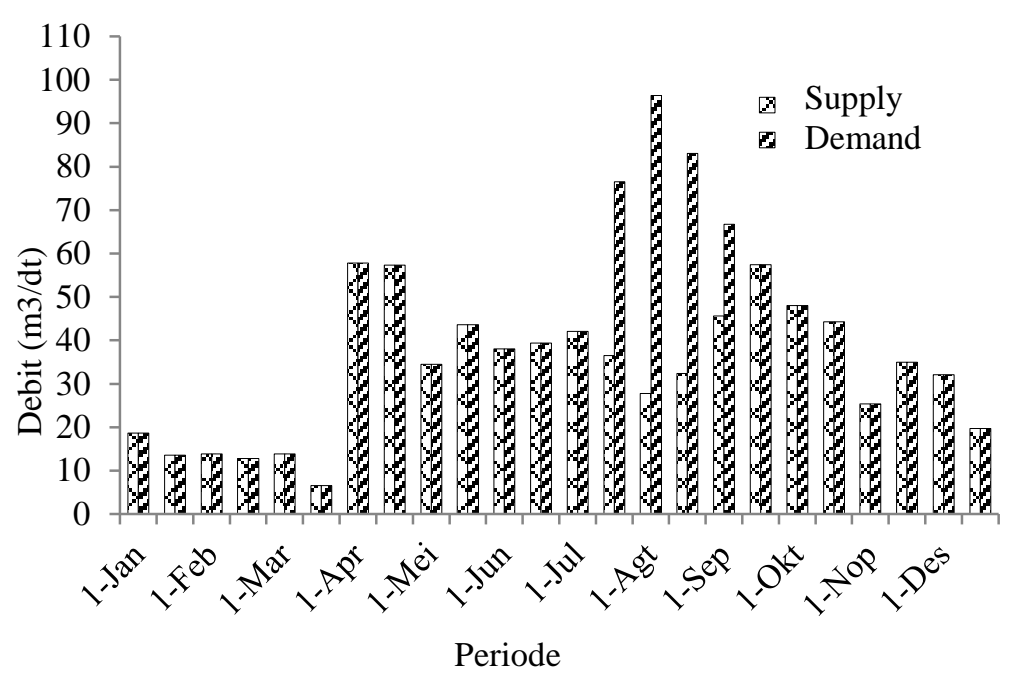

b)

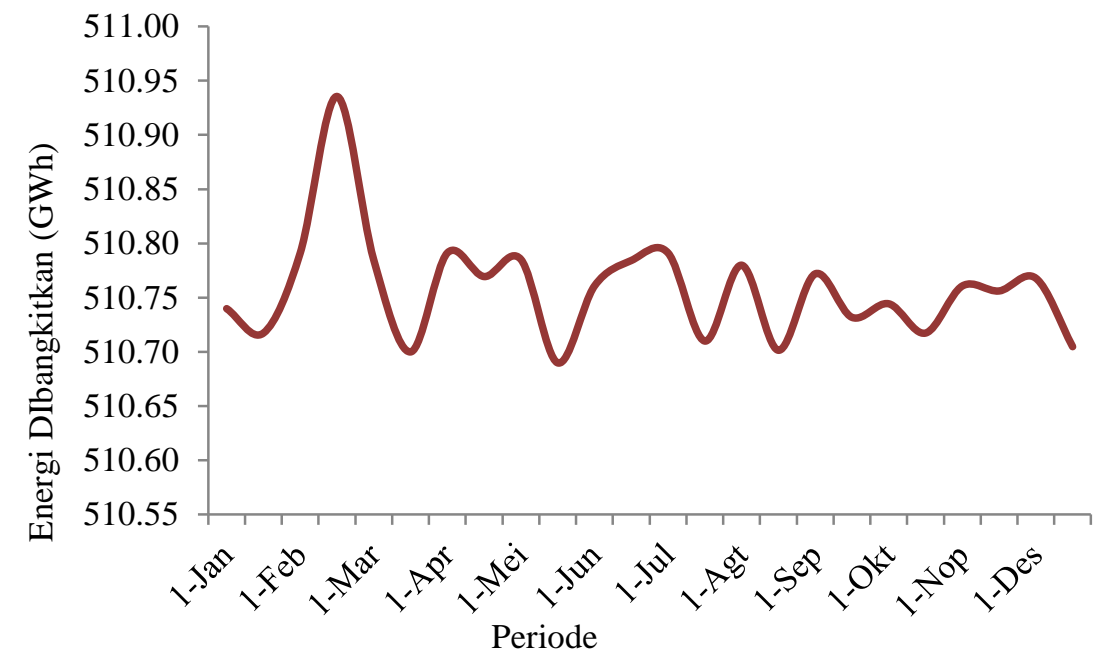

c)

Gambar 16. a) Demand dan supply air baku, b) Irigasi, c) PLTA kondisi 50 tahun mendatang

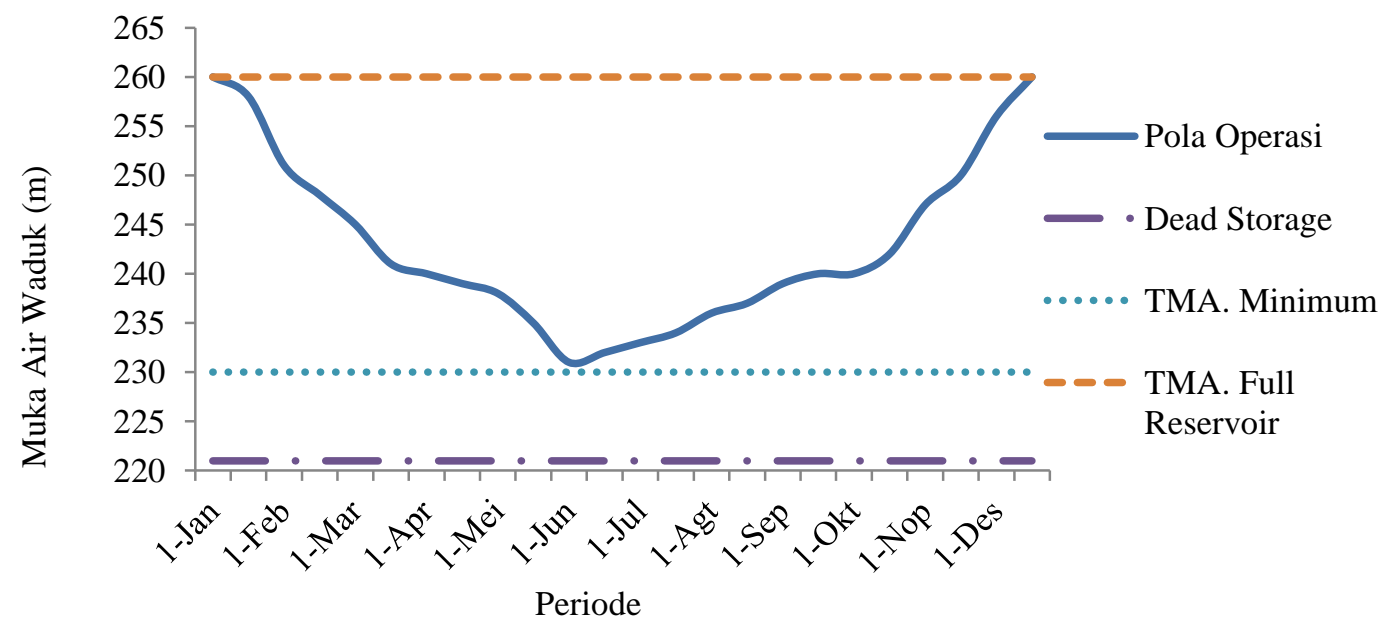

Gambar 17. Pola operasi Waduk Jatigede 50 tahun mendatang 


\section{Unjuk kerja waduk kondisi eksisting}

\section{Keandalan waduk}

Banyaknya periode sukses

Banyaknya periode operasi

$$
\begin{aligned}
& =341 \text { periode } \\
& =360 \text { periode } \\
& =95 \%
\end{aligned}
$$

\section{Kelentingan waduk}

Frekuensi terjadi masa transisi

dari sukses ke gagal

Banyaknya periode gagal

Jangka waktu rata-rata waduk

dalam keadaan gagal

Kelentingan waduk

$$
\begin{aligned}
& =10 \text { periode } \\
& =19 \text { periode } \\
& =19 / 10=1,9 \\
& =53 \%
\end{aligned}
$$

\section{Kerawanan waduk}

Total defisit

Jumlah periode gagal

Rata-rata defisit

$$
\begin{aligned}
& =589,653 \text { juta } \mathrm{m}^{3} \\
& =19 \text { periode } \\
& =31,034 \text { juta } \mathrm{m}^{3}
\end{aligned}
$$

Unjuk kerja waduk kondisi 50 tahun mendatang

\section{Keandalan waduk}

Banyaknya periode sukses

Banyaknya periode operasi

$=1108$ periode

$=1200$ periode

$=92 \%$

\section{Kelentingan Waduk}

Frekuensi terjadi masa transisi

dari sukses ke gagal

Banyaknya periode gagal

Jangka waktu rata-rata waduk

dalam keadaan gagal

Kelentingan waduk

$$
\begin{aligned}
& =61 \text { periode } \\
& =92 \text { periode } \\
& =92 / 61=1,51 \\
& =66 \%
\end{aligned}
$$

\section{Kerawanan Waduk}

Total defisit

$=1,751$ miliar $\mathrm{m}^{3}$

Jumlah periode gagal

Rata-rata defisit

$=92$ periode

$=19,037$ juta $\mathrm{m}^{3}$

\section{Kesimpulan}

Dari hasil analisis unjuk kerja dapat disimpulkan bahwa keandalan waduk dalam upaya memenuhi kebutuhan air baku, irigasi, dan PLTA pada kondisi eksisting adalah sebesar 95\%, kelentingan waduk sebesar $53 \%$, dan kerawanan waduk sepanjang periode simulasi sebesar 589,653 juta $\mathrm{m}^{3}$, Sedangkan pada kondisi 50 tahun mendatang keandalan waduk sebesar $92 \%$, kelentingan waduk sebesar 66\%, dan kerawanan waduk sepanjang periode simulasi sebesar 1,751 miliar $\mathrm{m}^{3}$.

\section{Saran}

Perlu ditinjau pengaruh beberapa aspek yang lain terhadap unjuk kerja waduk, seperti manajemen air irigasi, efisiensi irigasi, sebaran sedimen, pertumbuhan penduduk, dan perubahan iklim, sehingga hasilnya dapat digunakan sebagai masukan untuk pola operasi waduk di masa mendatang.

\section{Daftar Pustaka}

Balai Data dan Informasi SDA, PSDA Jawa Barat, (t,thn,). DAS Cimanuk, Profile Ekoregion Jawa.

Direktorat Jenderal Departemen Pekerjaan Umum, 1986. Standar Perencanaan Irigasi Kriteria Perencanaan 01, Departemen Pekerjaan Umum, Jakarta.

Direktorat Jenderal Pekerjaan Umum, 1986. Kriteriar Perencanaan Bangunan Utama 02, Departemen Pekerjaan Umum, Jakarta.

Direktorat Jenderal Sumber Daya Air, 2014. Efisiensi Penggunaan Air Solusi Kekeringan, http://sda,pu,go,id/index,php/berita-sda/datinsda/item/709-efisiensi-penggunaan-air-solusikekeringan.

PT. Indah Karya (Persero), 2009. Supervisi Pembangunan Waduk Jatigede, BBWS Cimanuk Cisanggarung, Cirebon.

PT. Multimera Harapan, 2013. Penyusunan Pedoman Operasi dan Pemeliharaan Bendungan Jatigede, BBWS Cimanuk Cisanggarung, Sumedang.

Sudjarwadi, 1987. Dasar-Dasar Teknik Irigasi, KMTS-UGM, Yogyakarta.

Sudjarwadi, 1990. Teori dan Praktek Irigasi, PAU Ilmu Teknik UGM, Yogyakarta. 